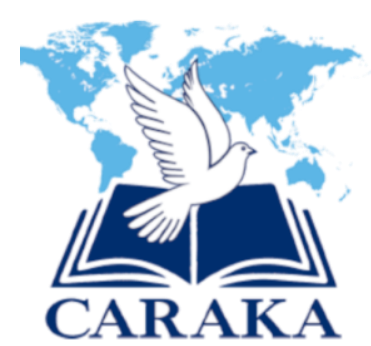

\begin{tabular}{|l|l|l}
\hline Diserahkan: 31 Agustus 2020 & Diterima: 02 Oktober 2020 & Diterbitkan: 05 November 2020
\end{tabular}

\title{
Keesaan Yahweh (Tuhan) Dalam Kitab Kejadian
}

\author{
Lamberty Yahya Mandagi \\ Fakultas Teologi Universitas Kristen Indonesia Tomohon (UKIT) \\ lambertymandagi@gmail.com
}

\begin{abstract}
This paper discusses the oneness of Yahweh in the book of Genesis, especially the parts of the book of Genesis which are considered as the work of Yahwist sources. Why conduct a study from parts of the Bible that come from Yahwist sources because this source is considered to be the oldest source in the Bible. The point about the oneness of Yahweh is lifted, because in the book of Genesis, there are certain passages that indicate that Yahweh is not singular but is plural. Therefore, the researcher conducted research related to this subject by doing hermeneutic work, specifically using a critical historical approach. Through literature research on texts related to the subject matter, it can be concluded that in the view of Yahwist sources, the Lord God (Yahweh Elohim) who is worshipped by the Israelites in the Old Testament is one. The one Yahweh is often accompanied by His angels. Thus, the same Lord God who is worshipped by Christians today is one God.
\end{abstract}

Keywords: Yahweh; Oneness; Book of Genesis; Yahwist.

\begin{abstract}
Abstrak
Tulisan ini membahas tentang keesaan Yahweh dalam kitab Kejadian, secara khusus dari bagian-bagian kitab Kejadian yang dianggap sebagai karya dari sumber Yahwist. Mengapa mengadakan kajian dari bagian-bagian Alkitab yang berasal dari sumber Yahwist karena sumber ini dianggap sebagai sumber yang tertua dalam Alkitab. Pokok tentang keesaan Yahweh diangkat, karena dalam kitab Kejadian, ada bagian-bagian tertentu seperti mengindikasikan bahwa Yahweh itu tidak esa adanya tetapi bersifat jamak. Karena itu penulis melakukan penelitian berkaitan dengan pokok ini dengan melakuan kerja hermeneutik, secara khusus menggunakan pendekatan historis kritis. Melalui penelitian literatur terhadap teks-teks yang berkaitan dengan pokok pembahasan, maka dapat disimpulkan bahwa dalam pandangan sumber Yahwist, TUHAN Allah (Yahweh Elohim) yang disembah oleh umat Israel dalam Perjanjian Lama, esa adanya. Yahweh yang esa itu seringkali didampingi oleh malaikatmalaikat-Nya. Dengan demikian, TUHAN Allah yang sama dan yang disembah oleh orang Kristen masa kini adalah Allah yang esa.
\end{abstract}

Kata kunci: Yahweh; Keesaan; Kitab Kejadian; Yahwist. 


\section{PENDAHULUAN}

Monoteisme Yahweh ( TUHAN) dalam kitab Perjanjian Lama sangatlah ditekankan dan merupakan credo yang sangat penting dari umat Perjanjian Lama bahwa TUHAN Allah yang disembah adalah Allah yang esa, sebagaimana yang terdapat dalam kitab Ulangan pasal 6 :4-5: "Dengarlah hai orang Israel: TUHAN itu Allah kita, TUHAN itu esa! Kasihilah TUHAN, Allahmu dengan segenap hatimu dan dengan segenap jiwamu dan dengan segenap kekuatanmu”.

Pengakuan akan ke-esaan TUHAN ini juga dikenal dengan sebutan "Syema" yang artinya adalah : Dengarlah. Syema itupun disebut sebagai dogma fundamental dari Perjanjian Lama dan disebut oleh Tuhan Yesus sebagai yang paling penting dari semua hukum (Mark. 12:29-30). ${ }^{1}$ Ketika orang seorang ahli Taurat bertanya kepada Yesus tentang hukum mana yang paling utama maka jawab Yesus: "Hukum yang terutama ialah: Dengarlah hai orang Israel, Tuhan Allah kita, Tuhan itu esa. Kasihilah Tuhan, Allahmu dengan segenap hatimu dan dengan segenap jiwamu dan dengan segenap akal budimu dan dengan segenap kekuatanmu” ( Mark 12: 29-30).

Jadi, Tuhan Yesus-pun mengajarkan bahwa TUHAN itu esa. Karena itu, pengakuan mengenai keesaan TUHAN ini adalah juga pengakuan gereja sepanjang masa bahwa sebagai persekutuan orang-orang yang mengaku percaya kepada Yesus Kristus, menyembah TUHAN Allah yang esa. TUHAN Allah yang esa itulah yang menjadi sumber pemberitaan gereja dan bukan dirinya sendiri. $^{2}$

Namun, dalam keyakinan kepada TUHAN yang esa itu, kadangkala mengalami "gangguan”, karena ketika membaca bagian-bagian Alkitab, khususnya dalam kitab Kejadian, memberi kesan seakan-akan TUHAN yang disembah bukanlah TUHAN yang esa tetapi bersifat jamak karena pengunaan kata "Kita" yang dikenakan kepada TUHAN oleh para penulis Akitab, antara lain yakni sumber Y (Yahwist), sebagai salah satu sumber terbentuknya kitab Taurat.

Karena itu penting sekali untuk membahas pokok ini demi mendapatkan pemahaman yang benar mengenai keesaan TUHAN, sebagai pokok iman yang sangat hakiki dalam kehidupan orang Kristen dalam mengimplementasikan imannya di tengah-tengah konteks majemuk masa kini. Adapun metode yang digunakan dalam penelitian ini adalah metode hermeneutik dengan pendekatan historis kritis.

\footnotetext{
${ }^{1}$ Herbert Wolf, Pengenalan Pentateukh (Malang: Gandum Mas, 1998), 297.

2 Robert Setio and Wahyu Widjaja, Teks Dan Konteks Berteologi Lintas Budaya (Jakarta: BPK Gunung Mulia, 2019), 181.
} 


\section{METODE PENELITIAN}

Metode yang digunakan dalam penyusunan artiel ini adalah metode penelitian kepustakaan (literatur) dengan menggunakan pendekatan hermeneutik, secara khusus metode historis-kritis. Yang menjadi sumber utama adalah Alkitab, terutama bagian-bagian dari kitab Kejadian yang berkaitan dengan pokok bahasan dan ditunjang dengan berbagai sumber, baik dari jurnal maupun dari buku-buku yang berkaitan dengan pokok bahasan. Bagian-bagian dalam kitab Kejadian yang dibahas adalah bagaian-bagian yang dianggap berasal dari sumber Yahwist. Sebelum masuk pada pembahasan diawali dengan pengenalan kitab Kejadian secara umum. Pada bagian akhir dari artikel ini penulis menarik kesimpulan tentang keesaan TUHAN Allah dalam kitab Kejadian menurut pandangan dari sumber Yahwist.

\section{HASIL DAN PEMBAHASAN}

\section{Mengenal Kitab Kejadian}

Kitab Kejadian adalah salah satu kitab dalam Pentateukh (Taurat) yang secara tradisional diyakini sebagai hasil karya dari Musa, dan kitab Kejadian adalah kitab yang menjadi dasar dari seluruh Alkitab (Genesis is the foundational book of the Bible ). ${ }^{3}$ Karena itu menurut Karen Amstrong, kitab Kejadian telah menjadi salah satu buku sakral yang telah memungkinkan jutaan pria dan wanita memahami bahwa kehidupan manusia memiliki dimensi kekal (Genesis has been one of the sacred books that have enabled millions of men and women to know at some profound lewel that human life has an eternal dimension). ${ }^{4}$

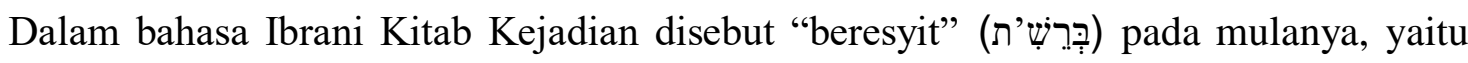
kata pembuka dari kitab tersebut. Menurut Lasor, nama ini sesuai, karena kitab Kejadian menceritakan awal segala sesuatu yang berhubungan dengan iman umat Allah dalam Alkitab. ${ }^{5}$ Dalam Vulgata (Alkitab berbahasa Latin), digunakan judul Genesis, dengan mengikuti terjemahan Septuaginta (LXX) pada abad ke 3 sebelum Masehi. ${ }^{6}$

Dalam bahasa Inggris, Genesis diterjemahkan dengan kata “ Origin” yang berarti asal mula, juga didasarkan pada kitab Kejadian pasal 1:1, In the begining, pada mulanya. ${ }^{7}$ Sejalan dengan itu, Mc Arthur mengatakan :

The English Title, Genesis, come from the Greek translation(Septuagint,LXX), meaning "origins"; whereas the Hebrew title is derived from the Bible's very first word,

\footnotetext{
${ }^{3}$ Skip Heitzig, You Can Understand The Book of Genesis (Oregon: Harvest House Publisher, 2018), 7.

${ }^{4}$ Karen Amstrong, A New Intrepretation of Genesis (Toronto: The Random House Publishing Group, 1997), 6.

${ }^{5}$ W. S Lasor, Pengantar Perjanjian Lama I (Jakarta: BPK Gunung Mulia, 1993), 111.

${ }^{6}$ E A Speiser, Genesis (Garden City: Doubleday Company, 1964), 17.

${ }^{7}$ Victor P Hamilton, The Book of Genesis Chapter 1-17 (Grand Rapids Michigan: William Eerdmans Publishing, 1991), 1.
} 
translated, "in the beginning." Genesis serves to introduce the Pentateuch (The first five book of the OT) and the entire Bible. ${ }^{8}$

Kitab Kejadian terdiri atas dua bagian besar, yaitu: Bagian pertama yang terdiri dari pasal 1-11 yang berbicara tentang "sejarah purbakala" (Urgeschichte), yaitu sejarah yang terjadi sebelum pemanggilan Abram; dan bagian kedua terdiri dari pasal 12-50 yang berbicara tentang sejarah nenek moyang Israel. ${ }^{9}$ Menurut Walter Bruggemann, kitab Kejadian terbagi dua bagian yang bersifat panggilan. Pasal 1-11. (God calls the world into being to be his faithful world) Allah memanggil dunia untuk menjadi dunia yang setia. Pasal 12-50 (God calls a special people to be faithfully his peole) Allah memanggil orang-orang istimewa untuk menjadi umat-Nya yang setia. ${ }^{10}$ Sedangkan menurut Claus Westermannn, kitab Kejadian dibagi dalam dua bagian yaitu pasal 1-11 disebut sebagai Sejarah utama/pertama (Primal History) dan pasal 12-50 disebut sebagai sejarah bapa-bapa leluhur (Patriarchal History). ${ }^{11}$

Kitab Kejadian sering disebut sebagai bagian dari Kitab Taurat Musa atau Taurat Musa, dengan menganggap bahwa Musa-lah yang menjadi penulis kitab ini, sebab sudah sejak lama orang beranggapan bahwa kitab Taurat adalah hasil karya atau buah pena dari Musa. Ini nyata bahwa tradisi Ibrani, Samaria dan Kristen menganggap bahwa Musa sebagai penulis Pentataeukh (Taurat) kecuali kisah kematiannya sendiri dalam Ulangan $34 .^{12}$ Dengan demikian pandangan tentang Musa sebagai penulis kitab Pentateukh sudah mengakar begitu kuat dalam alam pemikiran Yahudi, Ibrani, Samaria juga dalam Kekristenan, karena didasarkan pada beberapa ayat Alkitab, misalnya: Ulangan 31:9: " Setelah hukum Taurat itu dituliskan Musa, maka diberikannyalah kepada imam-imam bani Lewi, yang mengangkut tabut Perjanjian TUHAN, dan kepada segala tua-tua Israel”. Demikian pula dalam Injil Markus pasal 12 ayat 19: “ Guru, Musa menuliskan perintah ini untuk kita: Jika seorang yang mempunyai saudara laki-laki mati dengan meninggalkan seorang istri,..."

Pandangan bahwa Musa adalah satu-satunya sebagai penulis kitab Pentateukh lamakelamaan mulai diragukan, sebab dengan diadakannya berbagai studi kritis terhadap Pentateukh maka didapatkan adanya indikasi yang secara implisit menjelaskan bahwa Musa bukanlah penulisnya. Contoh ialah cerita tentang kematiannya sendiri sampai pada penguburannya ( Ulangan 34:1-12). Oleh karena itu disimpulkan bahwa ada orang yang menuliskannya.

\footnotetext{
${ }^{8}$ John Mc Arthur, Bible Commentary (USA: Thomas Nelson, 2005), 11.

${ }^{9}$ J Bloomendal, Pengantar Kepada Perjanjian Lama (Jakarta: BPK Gunung Mulia, 2013), 24.

${ }^{10}$ Walter Bruggemann, Genesis (Lousville: John Knox Press, 2010), 1.

${ }^{11}$ Clause Westermann, Genesis (Grand Rapids Michigan: William Eerdmans Publishing, 1986), 11.

12 Andrew E Hill and Walten J H, Survey Perjanjian Lama (Malang: Gandum Mas, 1996), 117.
} 
R.Norman Wybray mengatakan:

It has long been recognized that the traditional view-not stated in the Pentateukh itself, but already assumed elsewhere in te Old Testament-that Moses was the author of the Pentateuch cannot be correct. This conclusion was not derived from the fact that Moses' death an burial are recorded in the Pentateuch itself (Deut 34:5-8). ${ }^{13}$

Para ahli berpendapat bahwa sebenarnya Pentateukh disusun atau ditulis berdasarkan tradisi-tradisi yang telah ada lebih dahulu berupa tradisi-tradisi lisan (oral tradition). Sebagai contoh ialah adanya ungkapan-ungkapan seperti" "sampai hari ini" (Kejadian 32:32); Ulangan 34:10, "tidak ada nabi seperti Musa" (Ulangan 34:10) dan juga ungkapan tentang raja (Kejadian 36:31) walaupun kenyataannya belum ada raja yang muncul di zaman Musa. ${ }^{14}$ Karena itu telah menjadi pendapat umum bahwa berdasarkan penelitian yang dilakukan sejak abad 19 ternyata kitab Kejadian secara khusus, diredaksikan dari tiga sumber yang berbeda, yaitu Sumber Y (Yahwist), E (Elohist) dan P (Priest). Ronald Handel mengatakan bahwa ada tiga sumber utama dari Kitab Kejadian. The three major sources-known as the Yahwist (J), The Elohist (E), and the Priestly source-were carefully combined by one or more editors and later supplemented by some additional material. ${ }^{15}$ Dari ketiga sumber ini, sumber Y (Yahwist) diangap sebagai sumber tertua dan menjadi dasar dari seluruh Pentateukh ${ }^{16}$, teristimewa kitab Kejadian.

Sumber Yahwist diperkirakan berasal dari Israel Selatan (Yehuda) pada tahun 1000922 SM, Sumber E (Elohist), berasal dari Israel Utara, sekitar tahun 850 SM, Sumber P berasal dari zaman pembuangan Israel Selatan (Yehuda) di Babilonia pada tahun 587-555 SM. ${ }^{17}$ Atas dasar inilah maka tulisan ini dibatasi pada pembahasan bagian-bagian Kitab Kejadian yang berasal dari sumber Yahwist, karena sumber ini dianggap sebagai sumber yang tertua dimana dari segi ragam sastra dan gayanya menunjukkan bahwa komposisinya adalah pada masa pemerintahan raja Daud. ${ }^{18}$

Menurut Jean-Louis Ska, kitab Kejadian adalah suatu kumpulan dari cerita-cerita yang populer $^{19}$, dan ditinjau dari segi isinya, kitab Kejadian memang terbagi dalam dua bagian besar yang dapat dipisahkan secara jelas yaitu: Pasal 1-11, berisi tentang sejarah zaman permulaan (primeval history), mulai dari kisah penciptaan sampai pada kisah tentang menara Babel, yang kemudian diakhiri dengan daftar keturunan Sem dan keturunan Terah. Selanjutnya, pasal 12-

\footnotetext{
${ }^{13}$ R Norman Whybray, Introduction to The Pentateuch (Grand Rapids Michigan: William Eerdmans
} Publishing, 1995), 12.

${ }^{14}$ James M Efird, The Old Testament Writing (Lousville: John Knox Press, 1982), 36.

${ }^{15}$ Ronald Handel, The Book of Genesis (New Jersey: Pricenton University Press, 2013), 17.

${ }^{16}$ Wismoady Wahono, Di Sini Kutemukan (Jakarta: BPK Gunung Mulia, 1991), 56-57.

${ }^{17}$ Efird, The Old Testament Writing, 36.

${ }^{18}$ Robert B Coote and David Robert Ord, Sejarah Pertama Alkitab (Jakarta: BPK Gunung Mulia, 2016), 41.

\footnotetext{
${ }^{19}$ Jean Louis Ska, The Studu of The Book of Genesis: The Beginning of Critical Reading, In The Book:
} The Book of Genesis (Leiden: Hotei Publishing, 2012), 4. 
50, adalah sejarah para bapak lelehur umat Israel, yaitu Abraham, Ishak dan Yakub yang dapat dirinci sebagai berikut: Rangkaian cerita tentang Abraham (Pasal 12-26), rangkaian cerita tentang Esau dan Yakub (Kej 27-36) dan rangkaian cerita tentang Yusuf dan saudarasaudaranya (Kej 37-50).

\section{Karakteristik Sumber Yahwist}

Menurut Andrew E.Hill, ada beberapa karakteristik dari sumber Yahwist, yaitu: Pertama: Allah adalah Yahweh yang berjalan dan bercakap-cakap dengan kita. Kedua: Sumber ini menekankan pada berkat. Ketiga, penekanan terhadap pemimpin-pemimpin. Keempat: Bersifat narasi dan kisah-kisah. Kelima: Menekankan Yehuda. Keenam: Memakai istilah "Sinai”. Ketujuh: Sumber ini menyebut penduduk asli sebagai orang Kanaan. ${ }^{20}$ Secara lebih spesifik lagi, Blommendal mendaftarkan beberapa ciri khas dari sumber Yahwist:

Pertama, Allah disebut dengan Yahweh, juga nenek moyang Israel telah mengenal nama itu. Kedua, Allah digambarkan dekat dengan orang-otang pilihan-Nya sehingga Allah digambarkan dan dilukiskan sebagai seorang manusia. Ketiga, Sumber Y menggambarkan bahwa Allah adalah bersifat universal, khalik langit dan bumi dan Allah seluruh dunia dan semua manusia. ${ }^{21}$

Selain dipanggil untuk menjadi umat Allah, maka sumber Yahwist juga mengingatkan kembali tugas dari bangsa pilihan tersebut di tengah-tengah keterlibatannya dalam kancah international, yaitu untuk menjadi berkat bagi bangsa- bangsa yang ada disekitarnya dan bukan mendatangkan penderitaan atau penindasan. ${ }^{22}$

\section{Situasi Sosial, Politik,Ekonomi, Kebudayaan Saat Naskah Dituliskan.}

Karena sumber Yahwist berasal dari zaman raja Daud dan Salomo yang diperkirakan sekitar tahun 1000-920 SM, yakni di masa-masa jayanya kerajaan Israel raya yang dapat disebut juga sebagai "masa keemasan", maka ada baiknya untuk menelusuri situasi sosial, politik ekonomi, kebudayan yang berlangsung pasa saat itu dan melatarbelakangi munculnya karya sastra sumber Yahwist.

\section{Situasi di zaman pemerintahan raja Daud ( Tahun 1000-960 SM)}

Daud adalah raja yang menggantikan raja Saul setelah Saul mengalami kekalahan di medan pertempuran melawan orang Filistin. Sebelum Saul meninggal, Daud memamang telah diurapi terlebih dahulu oleh Samuel untuk menggantikan kedudukan Saul ( I sam 16:1-3).

\footnotetext{
${ }^{20}$ Hill and H, Survey Perjanjian Lama, 124.

${ }^{21}$ Bloomendal, Pengantar Kepada Perjanjian Lama, 18.

${ }^{22}$ Wahono, Di Sini Kutemukan, 65.
} 
Reputasi dari Daud memang sangat baik, sehingga ia cukup terkenal di antara suku-suku Israel. $^{23}$

Eksistensi Daud sebagai seorang raja menjadi jelas ketika sukunya sendiri Yehuda mengangkat dia sebagai raja mereka yang baru ( 2 Samuel 2:1-4). Daud kemudian mendapat tawaran dari para tua-tua Israel setempat untuk menjadi raja atas Israel bagian utara dan bagian Timur. Kesediaan dari para tua-tua untuk menerima Daud sebagai raja mengindikasikan adanya kemauan kesatuan diantara mereka. Keberhasilan Daud menjadi raja di Israel Raya mengagetkan bangsa Filistin, oleh karena itu penguasa Filistin menyusun strategi untuk memerangi Daud tetapi mereka sudah terlambat, sehingga orang Filistin sendiri dikalahkan oleh Daud (2 Samuel 5:17-25) karena Daud sudah memiliki kemampuan intelektual yang tinggi serta kecakapan militer yang terlatih lama. ${ }^{24}$ Daud merebut Yerusalem dan menempatkan Tabut Perjanjian di situ (2 samuel 6:12-15) sebagai simbol persekutuan suku-suku Israel dan lambang kehadiran Allah. Daud kemudian menaklukkan raja-raja di Kanaan, sehingga kerajaan Moab, Edom, Amon, Zoba dan Damaskus takluk di bawah kekuasaannya (2 Samuel 8:10,15-19; 12:26-31), bahkan Daud menjadi raja atas Amon, maka Daud mengambil Batsyeba, istri Uria, orang Het itu. ${ }^{25}$

Kekuasaan Daud meliputi daerah yang luas di asia Barat Daya dan di masa pemerintahannya orang Israel menjadi sangat kuat sehingga ia mampu memerintah suku-suku bangsa tetangganya. Israel menjadi kerajaan kesatuan yang membentang dari perbatasan Mesir sampai ke sungai Efrat. Ernst Ehrlich mengatakan:

Thus David kingdom stretched from the Gulf of Aqaba in the south to the territory of Homs in the north, and from the river (Euphrates) to the land of Philistines and the frontier of Egypt ( I Kings IV.21). ${ }^{26}$

Dengan kemenangan-kemenangan yang dialami Daud maka hal itu mendatangkan "kesejahteraan" dalam lingkungan kerajaan yang dipimpinya. Ditinjau dari segi ekonomi kerajan Israel di bawah kepemimpinan Daud mengalami kemakmuran, karena banyaknya upeti yang harus dibayar kepada Daud dari kerajaan-kerajaan di bawah kekuasaannya (2 Sam 8: 1-12), apalagi ketika raja Hiram dari Tirus mengirim berbagai perlengkapan dan juga para tukang untuk membangun istana raja. Demi menata kerajaannya yang baru dan yang sangat luas itu maka Daud melakukan berbagai kebijakan, sebab dalam kerajaan Israel selain sukusuku Israel yang mendiamnya, ternyata juga ada orang-orang Kanaan. Daud tidak menghilangkan kebiasaan-kebiasaan lama dari umat Israel, tetapi harus melanjutkan kebiasaan

${ }^{23}$ David F Hinson, Sejarah Israel Pada Zaman Alkitab (Jakarta: BPK Gunung Mulia, 1994), 116.

${ }^{24}$ Wahono, Di Sini Kutemukan, 134-135.

25 Ibid, 113.

${ }^{26}$ Ernst Ehrlich, A History of Israel (London: Dalton, n.d.), 35. 
umat untuk beribadah kepada TUHAN Allah. Di lain pihak juga, Daud tetap memberikan keluasan kota-kota Kanaan untuk terus melakukan ibadah kepada dewa-dewa mereka. Dengan adanya situasi seperti ini tidaklah tertutup kemungkinan untuk terciptanya suatu perjumpaan antara agama Kanaan dan agama Israel. Keterbukaan Daud terhadap agamaagama asli Kanaan mungkin juga disebabkan karena Daud memperistri Ahinoam, Yizreel, yang mungkin berasal dari daerah orang Keni, demikian juga Nabal dari Maon yang mungkin juga berasal dari suku Keni. ${ }^{27}$

\section{Situasi di zaman pemerintahan raja Salomo (961-922)}

Salomo menjadi raja Israel ketika kerajannnya sangat berkuasa dan musuhnya berkurang. Begitu ia memperoleh kekuasaan sebagai raja, ia segera bertindak dengan cepat untuk mempertahankan keutuhan wilayahnya dan menyingkirkan lawan-lawannya. ${ }^{28}$ Adonia kakaknya diperintahnya untuk dibunuh, demikian pula Yoab dan imam Abyatar yang telah memihak kepada Adonia diperintahkan untuk dibunuh (I Raja-raja 2:13-46). Selanjutnya Salomo memperkuat kota-kota perkubuan (I Raj-raja 9:15-19), memperlengkapi angkatan perangnya dengan kereta berkuda (I Raja-raja 4:26), dan mengadakan hubungan dengan kerajaan-kerajaan tetanggga, dengan mengawini putri-putri raja tersebut (I Raja-raja 11: 12)..$^{29}$

Selain berbagai pendapatan tersebut, Salomo juga menerima pajak dari raja-raja Arab (I Raja-raja 10:15) bahkan mendapatkan pemasukan lewat perdagangan kuda-kuda dan kereta, dimana ia membeli kuda dari Mesir dan kuda dari Kewe (Sisilia) lalu kemudian menjualnya kepada kerajaan-kerajaan yang kecil di utara Siria (I Raja-raja 10: 28-29). Ia kemudian tergiur dengan berbagai proyek-proyek besar lalu membangun gedung-gedung yang besar, namun tenaga kerjanya diambil dari luar karena Israel tidak memiliki tenaga kerja yang terampil. ${ }^{30}$ Perlu diingat karena penyelesaian pekerjaan pembangunan Bait Allah adalah hasil karya dari para pekerja yang berasal dari Funisia, maka ada kemungkinan adanya unsur-unsur agama Kanaan yang masuk dalam peribadatan umat Israel. Sebab desain bangunan yang digunakan adalah mengikuti tradisi disain bangunan Kanaan-Funisia. ${ }^{31}$ Dengan melaksanakan proyekproyek tersebut maka Salomo menjadi semakin ambisius, sehingga dana yang dikeluarkan menjadi sangat banyak. Ia kemudian mengambil jalan keluar dengan menagih pajak yang besar dari rakyat untuk mengimbangi biaya-biaya dalam lingkungan kerajaan maupun tenaga

\footnotetext{
${ }^{27}$ Martin Noth, The History of Israel (London: Adam \& Charles Black, 1976), 180.

${ }^{28}$ Wahono, Di Sini Kutemukan, 136.

29 Ibid.

${ }^{30}$ Hinson, Sejarah Israel Pada Zaman Alkitab, 123.

${ }^{31}$ Ibid.
} 
kerja. Salomo bahkanpun terlibat hutang dengan raja Hiram dari Tirus, sehingga pembayarannya secara terpaksa harus menyerahkan dua puluh desa di Galiliea untuk melunasi hutang (I Raja-raja 9: 10-14). Di akhir pemerintahan Salomo, kerajaan Israel mulai goncang, apalagi ketika ia terjerumus pada penyembahan berhala orang Moab, Amon, Edom, Sidon dan Het. Di saat itu pula muncul berbagai pergolakan dari bangsa- bangsa di bawah kekuasaan Israel, sehingga Israel akhirnya kehilangan kekuasaan atas Damsyik, dan beberapa daerah Edom. Demikian pula seorang pegawai Salomo yakni Yerobeam mengadakan pemberontakan, tapi akhirnya dia tidak dapat mengalahkan Salomo, sehingga ia melarikan diri ke Mesir. ${ }^{32} \mathrm{Hal}$ yang perlu diperhatikan, ketika Salomo jatuh pada penyembahan berhala, hal itu membuka peluang bagi sebagian umat untuk mengikuti jejak Salomo, sehingga terjadilah percampuran kebudayaan, keagamaan Israel dengan kebudayaan, keagamaan Kanaan.

\section{Kajian Perikop Dalam Kitab Kejadian Yang Berbicara Tentang Keesaan TUHAN.}

Karya-karya Yahwist dalam kitab Kejadian sangat banyak, karena sumber ini disebut sebagai dasar dari kitab Kejadian bahkan keseluruhan Pentateukh. Karena itu bagian-bagian yang akan dikaji adalah perikob-perikob atau juga lebih khusus ayat-ayat yang secara langsung berkaitan dengan pokok pembahasan, dimana oleh para ahli, khususnya E.A.Speiser, menganggap dokumen dari Yahwist, yaitu: Kejadian 2:4b-3:24; 4:17-26; 6:1-8; 9:1-17;12:14a,6-20;13:12b-18; 15:1-2a，6-12; 16:4-14;18:1-33; 19:1-28;24:1-67;21: 1a,2a,33;32:4-33; 43:1-34. ${ }^{33}$ Secara keseluruhan perikob-perikob tersebut di atas jika ditinjau dari jenis sastranya (literary genre) adalah bersifat narasi atau cerita (narrative). ${ }^{34}$

\section{Batas-Batas Perikop}

Karena dalam penelitian ini mengadakan pendekatan secara tematis dan bukan perikopis, maka perikop-perikop yang diulas lebih dari satu. Karena itu tidak semua perikop yang diangkat dijelaskan batas-batas perikopnya, tetapi perlu untuk memberikan contoh batas perikop. Sebagai contoh adalah naskah Kejadian 2:4b-3:24. Bagian ini terpisah dari Kejadian 1:1-2:4a, karena Kejadian 1:1-2:4a dianggap berasal dari sumber P ( Priest). ${ }^{35}$ Pasal 1:4a berbunyi: Demikianlah riwayat langit dan bumi pada waktu diciptakan. Kalimat ini mengindikasikan bahwa proses penciptaan langit dan bumi telah selesai. Sedangkan dalam pasal 2:4b, dimulai dengan kalimat: Ketika TUHAN Allah menjadikan bumi dan langit,-. Sangat jelas bahwa ini adalah unit yang terpisah, dan sebuah pernyataan untuk memulai suatu

\footnotetext{
32 Ibid.

${ }^{33}$ Hamilton, The Book of Genesis Chapter 1-17, 16.

${ }^{34}$ G Von Rad, Genesis (Britain: SCM Press, 1991), 386.

${ }^{35}$ Bloomendal, Pengantar Kepada Perjanjian Lama, 26.
} 
cerita. Dalam bagian ini tidak lagi menggunakan kata menciptakan (created) tetapi menjadikan (making). Selanjutnya dalam pasal 4:1. Dimulai dengan kalimat: Kemudian manusia itu bersetubuh dengan Hawa, isterinya,.. (Bahasa Ibrani: וֹדָאָדָם (wehaadam, dan Adam). Kalimat ini mengindikasikan bahwa pasal 4:-16 adalah kelanjutan cerita dari pasal $2: 4 b-3: 24$, dimana pada bagian akhir dari pasal ini mengisahkan tentang manusia yang diusir TUHAN Allah dari taman Eden.

\section{Kajian Hermeneutik Naskah Alkitab}

Dokumen Yahwist dalam kitab Kejadian bermula dari catatan Taman Eden dalam Kejadian 2:4b-3:24 sampai pada penaklukan, dipandang sebagai sumber teks yang tertua. ${ }^{36}$ Dalam Kejadian 2:4b-3:24, Yahwist memaparkan bahwa TUHAN Allah (Yahweh ${ }^{37}$ Elohim) adalah pencipta langit dan bumi berserta segala isinya, termasuk manusia. Proses penciptaan langit dan bumi menurut Yahwist lebih pendek dan sederhana daripada cerita penciptaan menurut sumber Priest (P) yang terdapat dalam Kejadian pasal 1:1-2:4a. Namun secara jelas Yahwist menggambarkan bahwa satu-satunya pencipta alam semesta ini adalah TUHAN Allah dimana tidak ada kuasa lain atau dewa-dewa lain yang turut campur tangan. Di sisi lain Yahwist mau mengatakan bahwa hanya ada satu pencipta. Ia adalah kekuatan tertinggi yang tidak memiliki tandingan, yaitu TUHAN Allah. TUHAN Allah itulah yang menjadikan segala sesuatu menurut kehendak-Nya sendiri. TUHAN Allah sebagai Sang pencipta diperkenalkan dengan nama Yahweh Elohim ( יהוֹה אֶלהּימ: ). Nama Yahweh adalah nama diri yang sebenarnya terdiri dari 4 huruf konsonan יהוה (YHWH) yang disebut "Tetragrammaton. Nama ini dibedakan dari El dengan bentuk variannya. ${ }^{38}$ Menurut Titaley, Yahweh adalah monoteis (tunggal) bukan politeis (jamak). ${ }^{39}$ Kata Yahweh di sini menunjuk nama pribadi, sedangkan kata Elohim, yang seakar dengan Allah menunjukkan nama benda. ${ }^{40}$ Dengan demikian kata Yahweh adalah mengartikan nama pribadi Allah. Nama Yahweh dapat dikatakan merupakan sebutan yang secara khusus lahir dalam konteks kepercayaan bangsa Israel. ${ }^{41}$ Penggabungan Yahweh Elohim dimaksudkan oleh penulis untuk mengidentikkan Yahweh, TUHAN perjanjian sebagai Allah sang pencipta. ${ }^{42}$

\footnotetext{
${ }^{36}$ Jan Christian Gertz and Angelika Berlejung, Puwa Pustaka: Eksplorasi Ke Dalam Kitab-Kitab Perjanjian Lama Dan Deuterokanonika (Jakarta: BPK Gunung Mulia, 2017), 175.

${ }^{37}$ Bette Jo Benner, Genesis A New Inptrepretation (USA: Xlibibris Coporation, 2013), 24.

${ }^{38}$ Eben Munthe, “Implikasi Penggunaan 'El' Dan 'YHWH" Dalam Kekristenan Masa Kini,” Kurios: Jurnal Teologi dan Pendidikan Agama Kristen 5, no. 1 (2019): 60.

39 John S Titaley, "Di Seputar Penerjemahan Nama Yahweh Dalam Alkitab Bahasa Indonesia," Waskita 3, no. 2 (2006): 145 .

${ }^{40}$ Donald Gutrhie, Tafsiran Alkitab Masa Kini I (Jakata: Yayasan Bina Kasih OMF, 1987), 32.

${ }^{41}$ Marthinus Theodorus Mawene, Perjanjian Lama Dan Teologi Kontekstual (Jakarta: BPK Gunung Mulia, 2020), 31.

42 Ibid, 82.
} 
Menurut von Rad, penggabungan kata Yahweh Elohim, adalah hasil kerja dari para redaktor di mana mula-mula kata yang digunakan adalah Yahweh. Pengabungan Yahweh Elohim adalah dalam rangka untuk lebih meyakinkan identitas dari Yahweh dan Elohim. ${ }^{43}$ יזוזה (Elohim) adalah gelar keilahian Allah yakni Pencipta. Bangsa Israel percaya bahwa אֶלהימ yang dibaca אָזנָ (Adonay) adalah nama TUHAN Allah Israel (Ul. 6:4-5). ${ }^{44}$ Yahweh Elohim adalah Sang pencipta, Ia sendiri yang berinisiatif untuk menciptakan langit dan bumi dan segala isinya serta berkuasa atas segala ciptaan-Nya itu. Jadi dapat dipahami bahwa Yahweh Elohim menurut pandangan sumber Y adalah Esa (satu) adanya. Keesaan Yahweh lebih nyata lagi dalam pasal 6:17, disebutkan: Sebab sesungguhnya Aku akan mendatangkan air bah meliputi bumi untuk memusnahkan segala yang hidup dan bernyawa di kolong langit, KJV: And, behold,I even I, do bring a flood of waters upon the earth, to destroy all flesh, wherein is the breath of life, from under heaven. Kata Aku dalam bahasa aslinya disebut ( אֶנִ = ani, sebagai kata ganti orang pertama tunggal), dan juga dalam pasal 7:4 disebutkan: Sebab tujuh hari lagi Aku akan menurunkan hujan ke atas bumi empat puluh hari empat puluh malam lamanya, dan Aku akan menghapuskan dari muka bumi segala yang ada, yang Kujadikan itu. Dalam ayat ini, kata "Aku” dalam, bahasa aslinya disebut (אָנָכִ =anoki, adalah juga kata ganti orang pertama tunggal). Pengunaaan kata ganti orang pertama tungal "Aku" mengartikan bahwa Yahweh (TUHAN) sebagai Sang pencipta adalah TUHAN yang Esa di mana Ia sendiri berinisiatif untuk mencitptakan langit dan bumi beserta segala isinya tanpa ada intervensi dari pihak manapun, dan juga berkuasa atas segala ciptaan-Nya itu.

Selain menggunakan kata ganti orang pertama tunggal, ternyata juga Yahwist menggunakan kata ganti orang ketiga jamak dalam rangka pengungkapan untuk pribadi TUHAN. Dalam hal ini sumber Y menggunakan kata "kita”. Misalnya dalam pasal 3:22: “ Sesunggunya manusia itu telah menjadi salah satu dari kita, tahu tentang apa yang baik dan yang jahat; maka sekarang janganlah sampai ia mengulurkan tangannya dan mengambil pula dari buah pohon kehidupan itu dan memakannya, sehingga ia hidup untuk selama-lamanya”. Demikian juga dalam pasal 11:7 Baiklah kita turun dan mengacaubalaukan di sana bahasa mereka, sehingga mereka tidak mengerti lagi bahasa masing-masing”. KJV: Go to, let us go down, and there confound their language, that they may not understand one another's speech.

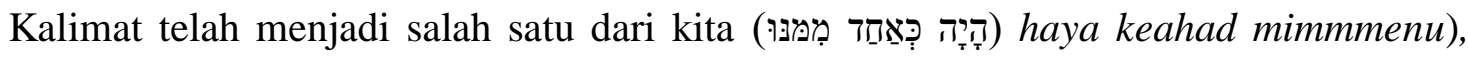

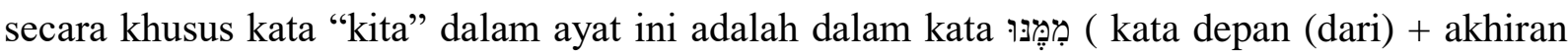
kata ganti orang I jamak umum (kita). Sedangkan kalimat baiklah kita turun (נֵרדָה , neredah) adalah kata kerja qal imperfect orang I jamak umum). Jadi sangat jelas bahwa dari bahasa

\footnotetext{
${ }^{43} \mathrm{Rad}$, Genesis, 77.

44 Juliman Harefa, "Makna Allah Pencipta Manusia Dan Problema Arti Kata 'Kita' Dalam Kejadian 1:26-27," EPIGRAPHE: Jurnal Teologi dan Pelayanan Kristiani 3, no. 2 (2019): 115. 
aslinya menggunakan kata ganti orang pertama jamak dan menggunakan kata kerja orang pertama jamak (menjadi salah satu dari kita, baiklah kita turun) become as one of us, let us go down, KJV).

Penggunaan kata kita dalam ayat-ayat tersebut di atas banyak menimbulkan berbagai spekulasi dan pertanyaan bahkan lebih daripada itu telah menimbulkan banyak interpretasi untuk mencari tahu apa sebenarnya maksud dari penulis ( Yahwist) mengunakan kata "kita" yang mana sekan-akan mengindikasikan bahwa sumber Yahwist menganut paham politeis. Menurut von Rad, Penggunaan kata kita di mulut TUHAN mengandaikan gagasan itu pada saat sebuah panteon, dewan para dewa. (The "we" in God's mouth presupposes the idea at one time of pantheon, a council of gods). ${ }^{45}$

Berkaitan dengan persoalan ini maka Victor P.Hamilton mendaftarkan bahwa ada enam pendapat yang dikemukakan oleh para ahli mengenai penggunaan kata "Kita":

Pertama, kata "Kita" melalui suatu penafsiran mitologis, dipahami bahwa hal itu menunjuk pada adanya dewa-dewi lain. Kedua, kata "Kita" menunjukkan adanya rombongan para malaikat, "anak-anak Allah" di mana yang berbicara adalah Allah sendiri. Ketiga, Allah berbicara dengan segala sesuatu yang telah diciptakan-Nya. Keempat, penggunaan kata" Kita" dari penulis, mungkin disebabkan dari segi tata bahasanya, sebab kata Allah (Elohim) bukan bersifat tunggal, tetapi bersifat jamak dengan adanya akhiran "im", yang menunuk pada akhiran orang ketiga jamak maskulin. Kelima, ahli-ahli tata bahasa yang lain menafsirkan bahwa penggunaan kata "Kita" menjadi suatu bentuk perundingan yang jamak. Allah sendiri yang berbicara pada diri-Nya sendiri. Keenam, kata "kita" sering dikaitkan dengan pengertian dari Trinitas tetapi kurang memakai terminology secara langsung. D.J.A. Clines, mengatakan bahwa Allah berbicara dengan Roh-Nya. ${ }^{46}$

Menurut Hamilton, penggunaan kata ganti orang ke tiga jamak "kita" adalah menggambarkan adanya ucapan dari Allah dalam suatu sidang ilahi, di mana dalam sidang itu terdapat para dewa atau malaikat-malaikat. ${ }^{47}$ Sedangkan menurut E.A. Speiser, penggunaan kata "kita" adalah menunjukan suatu " rombongan surgawi", yang mana hal tersebut masih tetap mengaburkan (tidak jelas). ${ }^{48}$ Joy A. Schroeder berkata bahwa penggunaan kata "Mari kita", dengan demikian misteri Trinitas secara terbuka dinyatakan (The mystery of the Trinity is openly declared). ${ }^{49}$

Berdasarkan beberapa pendapat yang dikemukakan di atas, sangat jelas bahwa di antara para ahli terdapat pandangan yang berbeda mengenai pokok ini. Tetapi pendapat Hamilton dan Speiser yang mengatakan bahwa penggunaan kata "kita" menunjukkan adanya percakapan antara Yahweh dengan para malaikat, di mana yang berbicara adalah Dia sendiri,

\footnotetext{
${ }^{45}$ Rad, Genesis, 149.

${ }^{46}$ Hamilton, The Book of Genesis Chapter 1-17, 133-134.

${ }^{47}$ Ibid, 208.

${ }^{48}$ Speiser, Genesis, 24.

49 Joy A Schroeder, The Book of Genesis (Grand Rapids Michigan: William Eerdmans Publishing,
} 2015), 58 
lebih dapat diterima. Sejalan dengan pendapat kedua ahli tersebut, nampaknya Yahwist memahami bahwa TUHAN selalu didampingi oleh para malaikat-Nya. Hal itu nampak jelas jika kita melihat pada pasal 18:1 dan 2, di situ diceritakan bahwa TUHAN menampakkan diri kepada Abraham dekat pohon tarbantin di Mamre, namun anehnya ketika TUHAN menampakkan diri kepada Abraham, yang dilihat Abraham bukan hanya satu orang saja melainkan tiga orang ( שֶׁלשה אָנָנשׁים , selosah anasim) berdiri di depannya. Ketiga orang

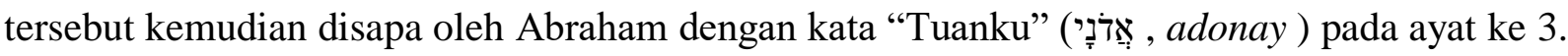
Tetapi juga dalam ayat 5, Abraham kemudian menyapa tamu-tamunya itu dengan sebutan tuan-tuan ( tuan-tuan telah datang, אָּרָרתמ , abartem, kata kerja qal perfect orang ke II maskulin tunggal ). Lalu kemudian pada ayat 13, disebutkan: Lalu berfirmanlah TUHAN

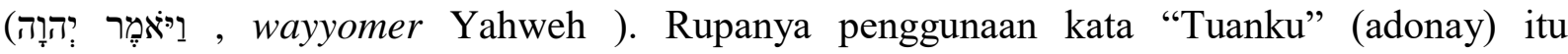
ditunjukkan untuk Yahweh (TUHAN). ${ }^{50}$ TUHAN datang menampakkan diri kepada Abraham bersama dengan kedua malaikat-Nya. Untuk lebih jelas lagi, dapat dilihat pada Kejadian pasal 18:22, di mana orang-orang itu (kedua malaikat) berjalan ke Sodom, tetapi Abraham berdiri di hadapan TUHAN. Dalam pasal 19:1 kemudian diceritakan bahwa kedua malaikat itu ( שְנֵי

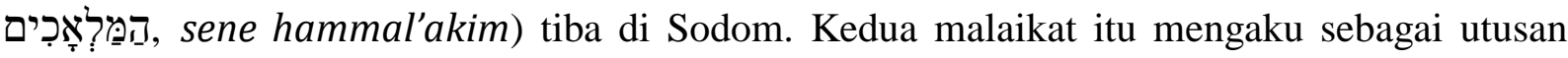
dari TUHAN. Mereka kemudian disapa oleh Lot dengan sebutan Tuan-tuan (אֶּנֵ ). Berbeda dengan penyapaan Abraham, Abraham menyapa dengan kata "Tuanku", sedangkan Lot menyapa dengan memakai kata "Tuan-tuan". Hal ini makin memperjelas bahwa TUHAN itu esa adanya menurut pandangan Yahwist, tetapi juga Ia mempunyai para malaikat yang selalu mengiringi-Nya.

Menurut Yahwist, Yahweh (TUHAN) yang esa itu, sebenarnya telah lama dikenal orang, sebab dalam pasal 4:26, di situ disebutkan bahwa ketika Set anak Adam memperanakkan Enos, maka pada saat itulah orang mulai memanggil nama TUHAN (Yahweh). Hal ini menunjukkan bahwa Yahweh yang esa itu, yang disembah oleh orang Israel adalah Yahweh yang universal, yang nama-Nya sudah lama diketahui orang.

Selanjutnya, Yahwist menggambarkan bahwa Yahweh memiliki anak (Kej 6:2). Menurt W.Lemp, memiliki anak dalam pengertian di sini bukanlah keturunan Allah dalam arti alamiah, melainkan anggota-anggota alam sorgawi, rombongan Allah. ${ }^{51}$ Jadi, anak-anak Allah yang dimaksudkan di sini sebenarnya hanyalah kata kiasan. Anak-anak Allah dapat juga diterjemahkan dengan anak-anak ilahi. ${ }^{52}$

Berkaitan dengan adanya pengungkapan anak-anak Allah maka von Rad mengatakan: namely, the sons of God are to be understood as angelic beings or as men, The

\footnotetext{
${ }^{50}$ Ibid, 129.

${ }^{51}$ Walter Lemp, Tafsiran Kitab Kejadian 5:1-12:3 (Jakarta: BPK Gunung Mulia, 1997), 32.

${ }^{52}$ Gutrhie, Tafsiran Alkitab Masa Kini I, 90.
} 
be neha lohim, here bay the way, clearly constrasted to the daughters of men, are beings of as sons of God, not in the physical, genealogical sense,i.e, mytologically, but generally as belonging to the world of the Elohim (cf. also b nehann biim, dicsiples of the prophets, II Kings 2-3,5,7). ${ }^{53}$

Yahwist kemudian berpandangan bahwa Yahweh itu memiliki Roh (Kej 6:3). Menurut pendapat Lemp, "rohku" di sini bukanlah karunia roh (kudus) yang memanggil dan menghinggapi para hakim dan nabi, melainkan adalah tanaga dan kodrat kehidupan jasmani seperti dalam Mzm 104. Tanpa roh Allah, manusia adalah debu. ${ }^{54}$

Yahweh (TUHAN) yang esa dan juga yang memiliki Roh itu adalah Yahweh yang berkuasa atas segala ciptaan, hanya dengan kehendak-Nya senndiri sehingga didatangkan-Nya air bah ke atas bumi. Ia pula yang berfirman kepada Nuh untuk beranak cucu dan memenuhi bumi (Kej 9:1) dan juga yang mengikat perjanjian dengan Nuh (9: 11-13). Yahweh itu pula kemudian disapa oleh Nuh sebagai Allah Sem (9:26).

Walter Lempp mengatakan:

Nama Sem telah diterangkan penafsir sebagai " orang kenamaan (Bahasa Ibrani "syem" berarti nama), bangsawan yang bertentangan dengan hamba Kanaan. Tetapi gelar syem terutama menunjukkan bahwa bangsa itu hanya mengenal dan memanggil "nama" TUHAN, "nama Yahweh. Kepada Sem (Israel) sajalah Allah membuka dan menyatakan nama-Nya: "Aku ada yang Aku ada" atau "Aku adalah Aku" (Kel 3:14, 6:2-3). Allah telah memperkenalkan nama-Nya, yaitu tabiat dan watakNya, kemuliaanNya dan kemauanNya kepada Israel saja. ${ }^{55}$

Yahweh yang dikenal oleh Nuh, itulah juga Yahweh yang kemudian dikenal oleh Abraham. Yahweh memanggil Abraham untuk pergi dari negerinya dan dari sanak saudaranya dan dari rumah bapanya ke negeri yang ditunjukkan Yahweh kepadanya. Yahweh kemudian mengikat perjanjian dengan Abraham bahwa Ia akan membuat Abraham menjadi bangsa yang besar, serta memberkatinya ( Kej 12:1-3). Melalui penampakan Yahweh kepada Abraham yang disertai dengan janji-Nya maka Abrahampun mendirikan mezbah bagi Yahweh (TUHAN), Kej ( 12:7-8).

Yahweh yang menampakkan diri kepada Abraham adalah Yahweh yang senantiasa menyertainya dan juga berfirman kepada Abraham bahwa Ia akan memberikan tanah Kanaan kepada Abraham serta keturunannya dan akan menjadikan keturunan Abraham seperi debu tanah (Kej 13 :14-16). Tentunya Abraham memahami bahwa Yahweh itu adalah esa adanya. Oleh karena itu Abraham kemudian menyapa Yahweh dengan sebutan "Adonay Yahweh" (Kej 15: 2,8). Dengan menggunakan kata "Adonay Yahweh", tentunya juga Yahwist

\footnotetext{
${ }^{53} \mathrm{Rad}$, Genesis, 114.

${ }^{54}$ Lemp, Tafsiran Kitab Kejadian 5:1-12:3, 33.

55 Ibid, 124.
} 
memberikan penjelasan bahwa Yahweh-lah Tuhan/tuan dari Abraham, dan tidak ada siapasiapa selain Dia.

Adonay Yahweh yang telah menampakkan diri kepada Abraham, Ialah juga yang telah menyatakan diri kepada Hagar, hamba Abraham melalui malaikat-Nya, sehingga Hagar menyapa Yahweh sebagai El-Roi (Kej 16:13: Kemudian Hagar menamakan TUHAN yang telah berfirman kepadanya itu dengan sebutan: "Engkaulah El-Roi." Sebab katanya: Bukankah di sini ku lihat Dia yang telah melihat aku?” ). Nampaknya juga Yahwist mau mengatakan bahwa Yahweh itu dapat juga disapa sebagai El. Hal tersebut Nampak juga lebih jelas di mana dalam pasal 21:33, disebutkan bahwa Abraham menanam pohon tamariska di Bersyeba dan memangil di sana nama TUHAN, Allah yang kekal. (Jadi, Yahweh (TUHAN) dapat juga disapa sebagai Allah yang kekal) . Hal ini menunjuk pada suatu pengakuan bahwa Yahweh bersifat kekal dan tidak akan pernah mengalami kebinasan. Rupanya penyebutan Yahweh sebagai Allah yang kekal sudah berkembang sejak periode pra-Israel. Dalam hal ini Allah yang kekal telah menjadi julukan untuk Yahweh. Von Rad mengatakan:

The notice about the cult of " the everlasting God" (to " call on the name of God" means to practice the cult) contains a very olt tradition, In the pre Tsralite period an " everlasting god" was worshiped in Beer-Sheba, Israel's ancestors the combined their "God of fathers" with this cult and thus name" Everlasting God" finally became an epithet of Yahweh. ${ }^{56}$

Selain dijuluki sebagai Allah yang kekal, Yahweh juga mendapat julukan sebagai Allah yang empunya langit dan empunya bumi (pasal 24: 3,7); Allah Abraham (pasal 24:12,27,42,48). Dalam perkembangan selanjutnya, kemudian disapa sebagai Allah Abraham, Allah Ishak (Kej 32:9: Kemudian berkatalah Yakub: "Ya Allah nenekku Abraham dan Allah ayahku Ishak, ya TUHAN, yang telah berfirman kepadaku: Pulanglah ke negerimu serta kepada sanak saudaramu dan Aku akan berbuat baik kepadamu). Yakub kemudian menyapa Allah ayahnya itu dengan sebutan Allah Yang Mahakuasa. (Pasal 43:14: Allah Yang Maha Kuasa kiranya membuat orang itu menaruh belas kasihan kepadamu,..).

Dengan adanya julukan-julukan bagi Yahweh, maka Yahwist pula mau menjelaskan bahwa Yahweh yang disembah oleh umat Israel, Dialah Allah para leluhur umat Israel, Ialah Allah yang kekal, Allah yang Mahakuasa yang melebihi segala allah-allah (dewa-dewa) sembahan bahngsa-bangsa lain. Hanya Yahweh yang layak untuk disembah dan dimuliakan oleh umat Israel. Ialah juga Yahweh yang disembah oleh Yusuf anak Yakub dan kemudian memberkatinya ( Kej 39:1-5).

\footnotetext{
${ }^{56} \mathrm{Rad}$, Genesis, 237.
} 


\section{KESIMPULAN}

Melalui pembahasan di atas, maka dapatlah disimpulkan bahwa Yahweh (TUHAN) adalah Allah yang esa. Dialah yang telah menciptakan langit dan bumi beserta segala isinya, termasuk manusia. Penggunaaan kata "kita" oleh sumber Yahwist tidaklah memberi pengertian bahwa Yahweh bersifat jamak, tetapi Dia itu esa adanya. Penggunaan kata "kita" dalam naskah sumber Yahwist dalam hubungannya dengan Yahweh, adalah ungkapan, percakapan TUHAN dengan para malaikat. Sebagai Allah yang esa, Ia didampingi oleh para malaikat-Nya, bukan dalam posisi yang setara dengan-Nya, tetapi sebagai utusan-Nya yang Ia ciptakan. Jadi penulis kitab Kejadian, khusunya sumber Yahwist, tidak memiliki paham politeis, tetapi paham monoteis dengan menggambarkan tentang kemahakuasaan-Nya yang tak terbatas, di mana Ia selalu diikuti oleh malakat-malaikat-Nya.

Di tengah pengakuan Yahweh sebagai Allah yang esa, ternyata Ia juga disapa dengan sebutan-sebutan gelar, antara lain: El- Roi (Allah yang melihat), El-Olam (Allah yang kekal) dan El-Shaday (Allah yang Maha Kuasa), bahkan juga disapa sebagai Allah Abraham, Ishak dan Yakub. Artinya ialah: Yahweh dapat saja diberikan gelar, berdasarkan pengalaman iman umat percaya, tetapi keberadaannya tetaplah esa (satu). Dalam hubungan dengan konteks penulisan naskah Yahwist ini, tentu hal ini mengingatkan umat Israel baik di zaman raja Daud maupun Salomo agar tidak terjerumus pada penyembahan berhala, sebagaimana terjadi pada Salomo, tetapi hanya menyembah kepada TUHAN Allah yang esa. TUHAN Allah yang esa yang diimani oleh umat Israel di masa lalu, secara khusus yang diberitakan oleh Yahwist, Dialah juga yang disembah oleh umat Kristiani ( Gereja) disepanjanng masa, yakni TUHAN Allah yang menyatakan diri dalam Yesus Kristus dan yang senantiasa hadir lewat kuasa Roh Kudus.

\section{DAFTAR PUSTAKA}

Amstrong, Karen. A New Intrepretation of Genesis. Toronto: The Random House Publishing Group, 1997.

Arthur, John Mc. Bible Commentary. USA: Thomas Nelson, 2005.

Benner, Bette Jo. Genesis A New Inptrepretation. USA: Xlibibris Coporation, 2013.

Bloomendal, J. Pengantar Kepada Perjanjian Lama. Jakarta: BPK Gunung Mulia, 2013. Bruggemann, Walter. Genesis. Lousville: John Knox Press, 2010.

Coote, Robert B, and David Robert Ord. Sejarah Pertama Alkitab. Jakarta: BPK Gunung Mulia, 2016.

Efird, James M. The Old Testament Writing. Lousville: John Knox Press, 1982.

Ehrlich, Ernst. A History of Israel. London: Dalton, n.d.

Gertz, Jan Christian, and Angelika Berlejung. Puwa Pustaka: Eksplorasi Ke Dalam KitabKitab Perjanjian Lama Dan Deuterokanonika. Jakarta: BPK Gunung Mulia, 2017. Gutrhie, Donald. Tafsiran Alkitab Masa Kini I. Jakata: Yayasan Bina Kasih OMF, 1987. Hamilton, Victor P. The Book of Genesis Chapter 1-17. Grand Rapids Michigan: William Eerdmans Publishing, 1991. 
Handel, Ronald. The Book of Genesis. New Jersey: Pricenton University Press, 2013.

Harefa, Juliman. "Makna Allah Pencipta Manusia Dan Problema Arti Kata 'Kita' Dalam

Kejadian 1:26-27.” EPIGRAPHE: Jurnal Teologi dan Pelayanan Kristiani 3, no. 2 (2019): 107-117.

Heitzig, Skip. You Can Understand The Book of Genesis. Oregon: Harvest House Publisher, 2018.

Hill, Andrew E, and Walten J H. Survey Perjanjian Lama. Malang: Gandum Mas, 1996.

Hinson, David F. Sejarah Israel Pada Zaman Alkitab. Jakarta: BPK Gunung Mulia, 1994.

Lasor, W. S. Pengantar Perjanjian Lama I. Jakarta: BPK Gunung Mulia, 1993.

Lemp, Walter. Tafsiran Kitab Kejadian 5:1-12:3. Jakarta: BPK Gunung Mulia, 1997.

Mawene, Marthinus Theodorus. Perjanjian Lama Dan Teologi Kontekstual. Jakarta: BPK Gunung Mulia, 2020.

Munthe, Eben. "Implikasi Penggunaan 'El' Dan 'YHWH" Dalam Kekristenan Masa Kini."

Kurios: Jurnal Teologi dan Pendidikan Agama Kristen 5, no. 1 (2019): 54-73.

Noth, Martin. The History of Israel. London: Adam \& Charles Black, 1976.

Rad, G Von. Genesis. Britain: SCM Press, 1991.

Schroeder, Joy A. The Book of Genesis. Grand Rapids Michigan: William Eerdmans Publishing, 2015.

Setio, Robert, and Wahyu Widjaja. Teks Dan Konteks Berteologi Lintas Budaya. Jakarta: BPK Gunung Mulia, 2019.

Ska, Jean Louis. The Studu of The Book of Genesis: The Beginning of Critical Reading, In The Book: The Book of Genesis. Leiden: Hotei Publishing, 2012.

Speiser, E A. Genesis. Garden City: Doubleday Company, 1964.

Titaley, John S. "Di Seputar Penerjemahan Nama Yahweh Dalam Alkitab Bahasa Indonesia." Waskita 3, no. 2 (2006): 145.

Wahono, Wismoady. Di Sini Kutemukan. Jakarta: BPK Gunung Mulia, 1991.

Westermann, Clause. Genesis. Grand Rapids Michigan: William Eerdmans Publishing, 1986.

Whybray, R Norman. Introduction to The Pentateuch. Grand Rapids Michigan: William Eerdmans Publishing, 1995.

Wolf, Herbert. Pengenalan Pentateukh. Malang: Gandum Mas, 1998. 